\section{ABSTRACT}

This article will critically review the evidence linking pneumonia to the aspiration of microbe-laden oropharyngeal secretions and tie that to the predisposition for these processes to affect dependent, medically compromised individuals. The goal of this review is to alert the reader to the role that oral disease and oral health play in fostering and preventing, respectively, widespread and potentially fatal pulmonary disease among high-risk individuals.

\section{MEY WORDSa nosocomial} pneumonia, pulmonary infection, bacterial pneumonia, respiratory pathogens, oral health, intensive care unit, long-term care facilities

\title{
Nosocomial Pneumonia and Oral Health
}

\author{
Kenneth Shay, DDS, MS ${ }^{1-4 *}$; Frank A. Scannapieco, DMD, PhD5; Margaret S. \\ Terpenning, MD ${ }^{3.6 .7}$; Barbara J. Smith, RDH, MPH, PhD ${ }^{2.4}$; George W. Taylor, \\ DMD, $\mathrm{DrPH}^{8}$
}

'Veterans Integrated Service Network \#11, Dept. of Veterans Affairs, Ann Arbor, Mich.; 'Dental Service; ${ }^{3} \mathrm{VA}$ Geriatric Research, Education, and Clinical Center, Ann Arbor VA Health Care System; 'Dept. of Periodontics/Prevention/Geriatrics, University of Michigan School of Dentistry, Ann Arbor; ${ }^{5}$ Dept. of Oral Biology, School of Dental Medicine, University at Buffalo, The State University of New York, Buffalo; ${ }^{6}$ Medical Service, Ann Arbor VA Health Care System; 'Dept. of Medicine, Section of Geriatric Medicine, University of Michigan Medical School, Ann Arbor; ${ }^{8}$ Dept. of Cariology, Restorative Sciences, and Endodontics, University of Michigan School of Dentistry, Ann Arbor; *Corresponding author: kenneth.shay@med.va.gov

Spec Care Dentist 25(4): 179-187, 2005

\section{Introduction}

The role that routine oral health, oral disease and oral hygiene play in acute infectious pulmonary disease in high-risk individuals, such as those residing in long-term facilities and intensive care units, is becoming more widely appreciated. Bacterial pneumonia is an inflammatory condition of the lung parenchyma, usually initiated by the introduction of bacteria into the alveolar sacs. ${ }^{1}$ The mouth and throat are richly populated by a vast number and numerous species of microorganisms, and aspiration of oral and pharyngeal secretions containing infectious agents is regarded by many prominent authorities as the most common route of non-pneumococcal pulmonary infection. ${ }^{1-4}$ Studies of both chronically and acutely ill patients have demonstrated that microbial deposits on the teeth and other oropharyngeal tissues of such individuals are commonly colonized with respiratory pathogens. ${ }^{4-10}$

In the late 1950s, more than two-thirds of Americans older than 75 were edentulous; in the first decade of the $21^{\text {st }}$ century, fewer than one-third of this age group is without natural teeth. ${ }^{11}$ The retention of some or even most of the dentition into advanced age extends the reach of oral and dental diseases into a life stage in which activities of daily living in general —and daily oral care in particular-are increasingly likely to tax or exceed the individual's capability to provide them. ${ }^{12}$ Aspiration of bacteria colonizing the teeth and other oral tissues is likely a key factor in pneumonia. ${ }^{4,5,7,8,13}$ Although many of the medical factors that predispose an individual to pneumonia are not readily modifiable, ${ }^{14.15}$ the means for addressing the oropharyngeal origins of the disease-such as providing adequate daily oral care-should be readily attainable for those residing in health care settings. Yet there is abundant documentation of inadequate provision of oral care in institutions ${ }^{16,17}$ and of the ongoing barriers responsible for that inadequacy. ${ }^{18-22}$

This article will critically review the evidence linking pneumonia to the aspiration of microbe-laden oropharyngeal secretions and tie that to the predisposition for these processes to affect dependent, medically compromised individuals. The goal of this review is to alert the reader to the role that oral disease and oral health play in fostering and preventing, respectively, widespread and potentially fatal pulmonary disease among high-risk individuals.

\section{Epidemiology}

Pneumonia may be communityacquired, wherein the infection by an agent such as a bacterium (most commonly Hemophilus influenza or Streptococcus pneumoniae) or virus is contracted by an individual residing in a non-institutional setting. The incidence of communityacquired pneumonia is approximately $12 / 1,000$ persons annually in industrialized 
countries, ${ }^{14}$ and mortality is 7 percent. ${ }^{9}$ Annual incidence rises to $34 / 1,000$ persons for those adults 75 and older. ${ }^{14}$ Alternatively, pneumonia can be nosocomial, in which the infection (most commonly caused by Staphylococcus aureus or one of a variety of gram-negative bacilli) is diagnosed in an individual residing in a hospital or residential health care facility (such as a nursing home), several days after his or her admission.

Nosocomial infections affect almost 5 percent of all hospital admissions, and pneumonias represent 10 percent to 15 percent of these infections. Nearly 300,000 hospital-acquired nosocomial pneumonias per year are reported in the United States (more than half of these in people older than $65^{23}$ ), resulting in more than 20,000 deaths (of which 84 percent are in people older than 65) and costing upwards of $\$ 2$ billion for treatment. ${ }^{6}$ Patients who are mechanically ventilated are at particular risk for nosocomial pneumonia. Ventilator-associated pneumonia (VAP) frequencies vary between 8 percent and $28 \%$ of all patients who are intubated. Crude estimates of intensive-care unit mortality rates of 24 percent to 76 percent have been reported for VAP at various institutions. ${ }^{24}$ The proportion of all hospital pneumonias that is nosocomial is difficult to ascertain, but reports place it in the 33 percent to 50 percent range. 14,15

Nursing home-acquired pneumonia is the leading cause of death in the nursing home population. ${ }^{14}$ It is the second most common infection in long-term care facilities (after urinary tract infections and before skin infections), accounting for 21 percent of all nursing home infections and affecting 18 percent to 48 percent of nursing home residents each year. ${ }^{25}$ Its incidence among longterm care residents has been variously estimated as $0.27-2.5 / 1,000$ patient days, with a median value of $1 / 1,000$ patient days. ${ }^{14}$ It is the single most common cause of hospitalization among this population. ${ }^{26}$ Mortality has been reported to be as high as 44 percent. ${ }^{27}$ Length of hospital stay for nursing home-acquired pneumonia ranges from 21-40 days, costing $\$ 9,460$ to $\$ 33,430$ per episode of care. ${ }^{25}$
Investigators stipulate a range of findings that must be present to identify a case of nosocomial pneumonia, which obscures confidence in prevalence and incidence figures as well as identification and quantification of risk factors for the disease. There is, however, uniform agreement $t^{1,4,7,14,27-32}$ that a chest radiograph identifying new-onset infiltrate is essential for diagnosis and that such radiological evidence alone is insufficient. There is less agreement about the additional criteria that must be present. Most authors have specified that a single additional sign be present, although at least two $\mathrm{O}^{4,30}$

\section{Scannapieco et al.} undertook a systematic review of the literature up to April 2002, evaluating a link between pulmonary and periodontal diseases. Their conclusions, accepted by a scientific review board of the American Academy of Periodontology, were that the evidence supports the existence of an association between

nosocomial pneumonia
and poor oral health in
high-risk patients.

have required two signs. The signs stipulated have included fever (variously non-quantified ${ }^{1,33}$ or specified as $>99.5^{\circ} \mathrm{F}_{\rightarrow}^{31}$ $>100.5^{\circ} \mathrm{F}^{29}>101.5^{\circ} \mathrm{F}^{26}>38^{\circ} \mathrm{C},{ }^{7}>38.5^{\circ} \mathrm{C},{ }^{30}$ $<35.5^{\circ} \mathrm{C}^{4}$ or $<36^{\circ} \mathrm{C}^{7}$ ), cough, subjective dyspnea, pleuritic pain, respiratory rate $>25$ breaths/minute, sputum production, decreased mental status, decreased physical function, decreased appetite, incontinence, falls, tachycardia, a positive chest exam (rales, ronchi and localized dullness to percussion), a history of known predisposing factors (e.g., a transparently circular criterion), a witnessed aspiration, gastric contents detected in an endotracheal tube, positive cultures (blood or sputum), and elevated white cell count (variously cited as $>5,000$ $\mathrm{wbc} / \mathrm{ml}$ above baseline $\mathrm{e}^{31}$ and $>10,000$ $\left.\mathrm{wbc} / \mathrm{ml}^{7}\right)$ or depressed white cell count $\left(<3,000 \mathrm{wbc} / \mathrm{ml}^{7}\right)$.

Predictably, the wide range of inclusion criteria in the literature has yielded concomitant variations in the lists of risk factors identified. Medina-Walpole and $\mathrm{Kat}^{2 r}$ summarized these and noted general agreement that alteration in neurological status, or a clinical condition indicating the same, is a key predisposing factor: drug or ethanol intoxication, anesthesia, seizure disorder, history of cerebrovascular disease, dysphagia, use of a feeding tube or mechanical ventilator, dependence for feeding, residence in a nursing home or use of sedative-hypnotic agent. ${ }^{7,13,27,29,31,34}$ Several authors have included functionality criteria such as dependency in activities of daily living, bedfast status, immobility, impaired locomotion, weight loss and frailty., ${ }^{4,13,35,36}$ Pulmonary disease, history of smoking, residence on an intensive care unit (ICU) and being immunocompromised also are often cited. . $^{1,27,31,34}$ Some predisposing conditions that are based on specific, presumed mechanisms include antipsychotic use (resulting in pseudoparkinsonism with consequent dysphagia ${ }^{37}$ ), bowel obstruction (leading to emesis1) and antacid or $\mathrm{H} 2$-blocker use (thereby reducing gastric acidity and supporting the viability of regurgitated bacteria ${ }^{34}$ ). Age is frequently cited as a predisposing factor. Medina-Walpole and Katz ${ }^{27}$ associate this increase among the elderly with age-related decreases in lung elasticity, forced expiratory volume vital capacity and host immunity, as well as an increased prevalence among older adults of cardiovascular accidents, gastro-esophageal reflux disorder, diabetes mellitus, presbyesophagus and the use of sedative hypnotics. Factors related to oral health and function include number of carious teeth, presence and/or concentration of 
cariogenic and periodontopathic organisms, number of functional teeth, poor oral hygiene, dependence on others for oral hygiene, dependence on others for feeding, difficulty managing oral secretions and mechanically altered diet. ${ }^{31,36}$

Risk factors that have been identified as statistically significant for pneumonia only can be derived from studies that have strictly defined case criteria. Reporting on a prospective study of 189 elderly veterans residing in a Veterans Administration nursing home, Langmore et al. ${ }^{36}$ limited cases of aspiration-related, nursing home-acquired pneumonia to those patients with specific radiological, clinical and laboratory findings subsequently reviewed and deemed unambiguously diagnostic by a panel consisting of a geriatrician, a geriatric cardiologist and a pulmonologist. In their study, multivariate logistic regression analysis demonstrated that significant predictors for acquiring disease included dependence for feeding, dependence for oral care, tube feeding, currently smoking, multiple medical diagnoses, number of medications and number of carious teeth. Over an eight-year period, Terpenning et al. ${ }^{31}$ followed 358 veterans age 55 and older, 50 of whom developed nursing-home acquired pneumonia that was unambiguously related to aspiration according to the criteria (and panel) described in Langmore et al. ${ }^{36}$ Logistic regression models demonstrated that statistically significant risk factors for patients with no natural teeth included chronic obstructive pulmonary disease, diabetes, dependence with feeding and presence of Staphylococcus aureus in saliva. Risk factors for patients with natural teeth included the preceding factors plus number of carious teeth, number of pairs of opposing teeth, and presence of caries and periodontal disease-causing organisms in saliva or dental plaque, respectively.

In a retrospective analysis that was much less restrictive in its definition of cases, Langmore et al. ${ }^{25}$ examined the Minimum Data Set/Resident Assessment Instrument reports from three U.S. states for a one-year period, representing nearly 103,000 nursing home residents. In this analysis, the dependent variable was the appearance of the ICD-9-CM code for "pneumonia (cause unspecified)"; independent variables were derived from other responses or groups of responses in the $350+$-item assessment completed by registered nurses. In this manner, the authors derived a one-year incidence for pneumonia of 3 percent, which is much lower than other published incidences for nursing home-acquired pneumonia (13 percent to 48 percent reported by Medina-Walpole and $\mathrm{Kat}^{27}$ ), suggesting that the case numbers were either limited due to underreporting, counting only those cases not transferred for hospitalization, coding of many admissions as due to other co-morbid conditions or to a combination of the three. Despite these uncertainties, however, the predictors found to demonstrate statistical significance-from the strongest to the weakest-were suctioning use, chronic obstructive pulmonary disease, chronic heart failure (CHF), feeding tube, bedfast status, high case mix (low functionality/ high-dependency), delirium, weight loss, swallowing problems, urinary tract infection, mechanical diet, dependence for eating, medical immobility, impaired locomotion, number of medications and age. While these correlations were largely consistent with the previously cited two reports, Langmore et al. ${ }^{25}$ commented on the absence of correlation with oral disease established by this sample. The oral health section of the Minimum Data Set/Resident Assessment Instrument has been shown to grossly underreport the extent of oral disease in long term care populations, ${ }^{38}$ a shortcoming of the instrument that likely accounts for oral health indices failing to emerge as predictors for pneumonia in this study.

Scannapieco et al. ${ }^{13}$ undertook a systematic review of the literature up to April 2002, evaluating a link between pulmonary and periodontal diseases. Their conclusions, accepted by a scientific review board of the American Academy of Periodontology, were that the evidence supports the existence of an association between nosocomial pneumonia and poor oral health in high-risk patients. More recently, El-Solh et al. ${ }^{4}$ prospectively followed 49 critically ill-but pneumonia-free-nursing home residents admitted to an ICU. Oral health indices and quantitative cultures of dental and denture plaque were obtained on ICU admission. Fourteen of the patients developed hospital-acquired pneumonia, and the bacteriology of their lungs was sampled with protected-brush alveolar lavage. Twenty-eight of the subjects' plaque samples contained $>1 \%$ aerobic respiratory pathogens. Compellingly, in eight of the patients who developed pneumonia, bacterial genotypes of plaque organisms matched those from pulmonary lavage samples.

\section{Microbiology}

The relative prominence ascribed to the different taxa of microscopic organisms responsible for nosocomial pneumonia has changed as techniques for sampling have evolved. Bartlett and colleagues ${ }^{34}$ reported in 1974 that nearly 90 percent of cases were caused by anaerobic species, most of which are normally residents of the gingival sulcus. This conclusion was largely based on samples collected by transtracheal aspiration, a technique that has been shown subsequently to be susceptible to contamination by oropharyngeal secretions. ${ }^{40}$ More recent studies employing blind protected specimen brushes and/or bronchoalveolar lavage have reduced the estimates of cases due to anaerobes to one-third or less of the total. ${ }^{3,40}$ Aerobic and facultative organisms are now implicated in many, possibly even the majority, of cases of nosocomial pneumonia. Organisms identified, largely from intra-alveolar sampling, include species of Gram-negative bacilli such as Acinetobacter, Enterobacter, E. coli, Hemophilus, Klebsiella, and Pseudomonas; and coccal forms, notably S. aureus (both antibiotic-resistant and antibiotic-nonresistant forms), Streptococcus pyogenes, and S. pneumoniae. ${ }^{41}$ Many cases of nosocomial pneumonia seem to be polymicrobial, ${ }^{1,410}$ although distinguishing between colonization with an organism and infection by an organism may be difficult. ${ }^{?}$

The microbiological species found in the mouths and throats of patients in 
health facility settings have been found to be dependent on the environment and how long the subject has resided there. Valenti ${ }^{{ }^{2}}$ reported that the oropharynges of 6 percent of healthy, communitydwelling elders were colonized with Gram-negative bacilli; 13 percent of those in an intermediate care facility; 22 percent of those in skilled nursing centers; and 40 percent of elderly patients in acute hospital wards. Scannapieco et al. ${ }^{5}$ compared the dental plaque of residents of a medical ICU (MICU) to plaque of age-matched patients of an ambulatory clinic (controls) and found that 65 percent of the former were colonized with potential respiratory pathogens upon admission to the unit, but only 16 percent of controls were. Furthermore, 75 percent of the MICU patients with teeth or dentures were colonized in this manner; 37.5 percent of the subjects with no teeth and no dentures were colonized. Fourrier et al. ${ }^{7}$ studied 57 patients during their ICU stays, sampling plaque upon admission and then on the fifth and tenth days after admission. Twenty-three percent of samples were positive for aerobic pathogens the day of admission; 39 percent on Day 5; and 46 percent on Day 10. High correlation was found between species in plaque and those recovered from transtracheal aspiration, and between species in plaque and in saliva. Thirty-seven percent of the MICU residents developed a nosocomial infection, and having plaque that was positive for aerobic pathogens characteristically hospital-acquired was highly predictive for this outcome. Russell et al. ${ }^{8}$ compared the plaque of nursing home residents with that of age-matched community-dwelling elders, finding that the former had a greater volume of plaque and a greater tendency ( 14.3 percent versus zero) to be colonized with potential respiratory pathogens. It should be noted that corresponding changes in the oropharyngeal flora of health care workers among these different settings have not, to the authors' knowledge, been investigated but merit consideration.

Saliva contains $10^{8}$ anaerobes and $10^{7}$ aerobes per milliliter; secretions coating the mucosal surface of the pharynx generally support an order of magnitude fewer organisms. ${ }^{1.41}$ Hard surfaces in the oral cavity, such as teeth and dentures, serve as convenient substrates for numerous adherent organisms that, when left undisturbed, establish dense microbial plaques in a matter of hours or days. Hard surfaces in the oral environment, both natural (e.g., teeth) and prosthetic (e.g., fixed and removable dentures), therefore, can function as non-shedding substrates that foster bacterial adhesion and biofilm formation. These oral biofilms can become colonized by respiratory pathogens and therefore serve as a reservoir of lung infection.

\section{Pathogenesis}

Langmore et al ${ }^{36}$ employed a convenient paradigm for discussing the pathogenesis of nursing home-acquired pneumonia. The paradigm, which will be followed here, divides etiological factors into those that:

- promote the growth of pathogenic organisms;

- predispose to aspiration; and

- impair host defense against aspirated pathogens.

\section{Promotion of the Growth of Pathogenic Organisms}

Based on the work of Gibbons et al. ${ }^{43}$ and Johanson et al., ${ }^{44}$ Scannapieco and Mylotte $^{6,45}$ synthesized a hypothesis involving salivary adhesive proteins that promote or inhibit microbial adhesion to teeth and mucosal surfaces. The salivary protein fibronectin has been shown to be degraded by proteases in oral secretions. Salivary proteases are known to become elevated as a result of oral inflammation, particularly in the presence of active periodontal disease. The degradation of fibronectin and other protective proteins would favor the adhesion and colonization of the oral cavity by Gram-negative bacilli. ${ }^{40}$ This model connects the absence of adequate oral hygiene, dentate status and the use of dentures with oral colonization by respiratory pathogens (consistent with the correlation between dentate status and pneumonia incidence reported by Terpenning et al..$^{33}$ ).
Salivary hypofunction creates an environment favorable for colonization with Gram-negative pathogens in a corresponding manner as well as in other ways. ${ }^{47}$ In healthy individuals, normal saliva contains numerous antimicrobial components (e.g., histatins, defensins, cathelicidin, lysozyme, lactoferrin, lactoperoxidase) that maintain a balance among commensal oral microbial populations. Diminution of saliva due to acute and long-term effects of antineoplastic irradiation to the head and neck, pharmacological effect or other factors (e.g., suctioning, lack of oral stimulation due to tube feeding, dehydration) may promote overgrowth of some bacterial strains through reduction or removal of these biological controls..$^{48}$ The pharmacological effect is most marked for pharmacological agents with anticholinergic side effects (e.g., sedative-hypnotics, neuroleptics, antidepressants) and can be severe for those medications in which acetylcholine blockade is the primary mechanism of action (e.g., oxybutynin [Ditropan ${ }^{\circledR}$ ], trihexphenidyl [Artane ${ }^{\circledast}$ ], and benztropine mesylate $\left[\operatorname{Cogentin}^{\otimes}\right]$ ). Without reference to the properties of specific agents, $\mathrm{Wu}$ and Ship ${ }^{50}$ reported that salivary flow rate of elderly, community-dwelling adults was inversely correlated to the number of medications ingested daily. This same correlation was independently demonstrated in both community- and institution-dwelling elderly groups by Loesche et al. ${ }^{41}$

Drug-related salivary hypofunction and the resultant reduction in salivary protection from oral fibronectin is consistent with the observations, described in the preceeding paragraph, of increasing the likelihood of plaque colonization by respiratory pathogens in persons taking more medications and less able to effectively remove dental plaque, typical of frail and institutionalized elders. The nursing diagnosis "dependence on others for oral care" also favors dental plaque development, particularly in long-term care settings, where numerous studies have reported the unfortunate but undeniable uniformity with which nursing staff overlook this particular, recurring, daily task of patient care. ${ }^{50}$ Other factors 
that impede oral hygiene, such as the presence of an endotracheal tube, also favor the establishment and preservation of oropharyngeal bacterial colonies. ${ }^{30}$

Another pharmacological factor that has been cited as favoring colonization is the recent use of any broad-spectrum antibiotic. ${ }^{27}$ It is not uncommon for both the mouth and the gut, each of them sites of huge numbers of many species of microorganisms, to experience superinfection when the normal balance of microbial populations is modified by an antimicrobial agent, such as one administered for urinary tract infection (the leading infection in the nursing home setting). Recent use of antibiotics has been linked with increased oropharyngeal colonization by antibiotic-resistant nosocomial pathogens. ${ }^{5.7}$ In addition, antacids and $\mathrm{H} 2$-blockers administered to ventilated patients to reduced stress-induced bleeding have been blamed for increasing the pathogenicity of regurgitated and aspirated gastric contents. ${ }^{34}$ Finegold ${ }^{1}$ notes that the de-acidifying action of these drugs reduces the bacteriostatic properties of stomach secretions, a function supported by the majority of the randomized clinical trials assessing gastric $\mathrm{pH}$ and/or pneumonia incidence as a function of antacid, H2-blocker or sucralafate (a cytoprotective agent) use..$^{34}$ Bonten and colleagues, ${ }^{51}$ however, have dismissed the stomach as a prominent source of respiratory pathogens. Scannapieco and Mylotte emphasized that the role, if any, played by regurgitated and aspirated stomach contents is probably minor in comparison with the role played by aspiration of the secretions of the extensively colonized oropharyngeal environment.

\section{Aspiration Risk}

Colonization of the upper airway with possible pathogens does not in itself pose a risk for pneumonia unless inocula of the pathogens are introduced into the lower airway. Aspiration has been reported to occur in more than 40 percent of healthy subjects during sleep and 70 percent of those with impaired consciousness. ${ }^{9}$ Factors that further predispose a host to aspiration are, not surprisingly, correlated with increasing risk for pneumonia.
Individuals with dysphagia due to a cardiovascular accident, Alzheimer's disease, parkinsonism, traumatic brain injury or other neurological disorders are at elevated risk for uncontrolled introduction of oropharyngeal material into the lower airway. ${ }^{34,52}$ Advanced age, by itself, has been shown to be correlated with increased incidence of aspiration, ${ }^{28}$ and community-dwelling elders who experience more aspiration during sleep are at increased risk for communityacquired pneumonia. ${ }^{53}$ Acute episodes of impaired consciousness, such as caused by delirium or a seizure disorder, predis-

\section{Hard surfaces in the oral}

environment, both natural (e.g., teeth) and prosthetic (e.g., fixed and removable dentures) can function as non-shedding substrates that foster bacterial adhesion and biofilm formation. These oral biofilms can become colonized by respiratory pathogens and therefore

\section{serve as a reservoir of lung infection.}

pose to aspiration as well. The physical presence of a solid object traversing the oropharyngeal, tracheal and bronchial regions, such as an endotracheal tube or suctioning apparatus, fosters internal dis semination..$^{34}$ Finally, the nursing diagnosis of "feeding dependency" reflects either the recognition of the patient's increased risk for aspiration or an increased likelihood that the patient's swallows will be rushed-hence impaired-by the inadvertently premature introduction of food into the mouth by another person. ${ }^{31,36.5}$
Bedfast patients-including those who are dependent for turning in bed and/or for getting out of bed-are less effective, for postural reasons, at expelling aspirated material. Individuals with a history of smoking, particularly those who continue to smoke, have impaired or absent ciliary function. This applies to individuals with chronic obstructive pulmonary disease as well; recent evidence has illustrated that patients with chronic obstructive pulmonary disease also tend to display impaired laryngeal elevation during swallowing. ${ }^{55}$ The cough reflex may be impaired by other respiratory disease, neurological disease (including recent stroke), congestive heart failure, hypophosphatemia, hypomagnesemia or medication use.

\section{Impaired Host Defense}

In the healthy individual, the potentially harmful effect of aspirated material is mitigated through a variety of mechanisms. Reflexive coughing, as elaborated above, expels the greatest volume of material. Secretions coating the airways entrap potential pathogens, and cilia maintain a steady movement of material out of the respiratory tract and into the esophagus. Pathogens that traverse the protective secretions or reach the alveolar sacs are dealt with through the various arms of the body's immune system: antibodies, complement, T-cells, neutrophils and phagocytes.

The immune system is sensitive to age and malnourishment, which also predisposes an individual to hyposalivation ${ }^{56}$. Elderly adults who are chronically debilitated, have experienced recent weight loss, suffer from hypoalbuminemia, or who are tube-fed will be less able to mount an adequate immune response to pulmonary pathogens.

\section{Prevention}

Preventive efforts directed at reducing the incidence and severity of nosocomial pneumonia are as multidimensional and numerous as the factors responsible for the disease. As such, approaches to prevention need to include: 
- those intended to reduce the number and virulence of potential pathogens likely to be aspirated;

- those intended to reduce risk of aspiration; and

- those focused on optimizing the patient's ability to adequately defend against aspirated pathogens.

While all reasonable and effective approaches should ideally be part of the preventive care plan for any at-risk older patient, preventive efforts must, at a min imum, be directed against the specific factors known or suspected as significant in a given case. ${ }^{25}$ The increasing retention of natural teeth into advanced age and the growing likelihood for impaired oral care with increasing age and infirmity combine to make preventive approaches intended to reduce the number and virulence of potential pathogens of particular importance. The following discussion will be limited to those.

Maintenance of oral health and provision of adequate oral hygiene need to be mainstay measures for preventing nosocomial pneumonia ${ }^{11,57}$ because respiratory pathogens colonize the dental plaque of frail individuals. ${ }^{4,5,-10}$ Individuals older than age 85 have the highest rate of need for support in one or more activities of daily living, are retaining an unprecedented proportion of their natural teeth, and are the group most likely to have prosthetic replacements (dentures, partial dentures, bridges and implants) for missing teeth. "The dental literature has abundantly demonstrated that growth and maturation of dental plaque can be readily controlled, regardless of the patient's age, through a routine of systematically scrubbing every accessible tooth and intraoral prosthesis surface in the mouth at least every 24 hours. ${ }^{58}$

A systematic review ${ }^{13}$ summarized and meta-analyzed the efficacy of recently described health worker-administered oral interventions intended to reduce the incidence of nosocomial pneumonia. This information, abstracted and updated with two additional studies, ${ }^{59,60}$ appears in Table 1 on the following page. Collectively, these studies report a reduction of pneumonia incidence averaging 40 percent through the application of a variety of oral care regimens. The findings also reinforce the concept that oral colonization by respiratory pathogens, fostered by poor oral hygiene and possibly periodontal inflammation, predisposes high risk patients to pneumonia.

Unfortunately, although daily oral hygiene is a self-care measure that nursing staff in hospitals and long-term care facilities are expected to support and/or provide, as necessary, numerous studies ${ }^{18-22}$ have demonstrated that this particular duty is typically overlooked for a variety of reasons. In light of this finding, several investigators ${ }^{69,70}$ have explored the

\section{An important obligation for dental professionals working with medical and nursing personnel is to be vigilant in educating their non-dental colleagues not only about the integral importance of effective oral hygiene and dental prosthesis care but also about the deleterious oral effects of medications.}

efficacy of different variations to resident-provided toothbrushing for minimizing the bacterial load accessible to aspiration. Persson et al..$^{71}$ reported the results of daily or weekly rinsing for 30 seconds with 0.12 percent chlorhexidine gluconate by elderly residents of retirement centers. A variety of indices of oral health, including direct and indirect measures of plaque and concentrations of periodontal and caries pathogens, showed significant improvement in the six weeks of the trial and for two weeks following. Common objections to the use of chlorhexidine - tooth staining and blunting of taste perception-were not observed. Simons et al. ${ }^{72}$ reported on a one-year trial of chewing gum containing chlorhexidine by elderly residential home residents. Salivary flow improved, but although all caries and periodontal pathogen indices declined, none did so to a statistically significant degree. It should be noted that long-term studies of the use of chlorhexidine for oral health have demonstrated that, while the agent is effective against causative organisms of caries and periodontal disease, it is relatively ineffective against non-periodontopathic Gram-negative organisms (which have been reported to be more prevalent with increasing age, regardless of a subject's institutional or non-institutional residence ${ }^{42}$; and which are responsible for a large proportion of nosocomial pneumonias). Daily povidone-iodine swabbing of the mouth and oropharynx, as employed by Yoneyama et al., ${ }^{68}$ was shown to effectively reduce pneumonia in nursing home residents, although this is an approach to oral care that many might consider unacceptably unpleasant.

No clinical trials have been reported that explore the impact on nosocomial pneumonia incidence of modifying medication regimens to exclude xerogenic and/or broad-spectrum antibiotics. In the presence of adequate daily oral hygiene, the impact of such measures likely would be marginal. But in settings and cases where daily oral care is inadequate, the decreased intrinsic protective mechanisms and/or additional oral microbial load resulting from these would exacerbate the risk for oropharyngeally seeded pulmonary disease. ${ }^{31.33,4}$

An important obligation for dental professionals working with medical and nursing personnel is to be vigilant in educating their non-dental colleagues not only about the integral importance of effective oral hygiene and dental prosthesis care but also about the deleterious oral effects of medications. Finally, the role that xerostomia in particular may play in the oral disease-pneumonia connection should be stressed wherever relevant.

\section{Conclusion}

Health care providers need to fully appreciate the important role played by aspiration of oropharyngeal secretions in initiating pneumonia. Factors that dis- 


\section{Table 1. Intervention Studies Supporting Efficacy of Improved Oral Care to Prevent Pneumonia.}

\begin{tabular}{|c|c|c|c|}
\hline Reference & Mo. of subjects (study/placebo/control) & Results (placebo vs. control) & Conclusion/Comments \\
\hline $\begin{array}{l}\text { Jugin et al. } \\
1991^{61}\end{array}$ & $\begin{array}{l}52 \text { ICU patients. } 25 \text { in test group, } 27 \\
\text { in placebo group. }\end{array}$ & $\begin{array}{l}\text { Tracheobronchial colonization by gram-nega- } \\
\text { tive bacteria and S. aureus, as well as pneu- } \\
\text { monia, occurred less frequently ( } p=0.0001 \text { ) in } \\
\text { the antibiotic (polymixin-neomycin-vancomy) } \\
\text { group than in the placebo group. Topical } \\
\text { oropharyngeal antibiotic application lowered } \\
\text { the rate of VAP by a factor } 5 \text {. }\end{array}$ & $\begin{array}{l}\text { In critically ill patients, topical oropharyngeal } \\
\text { antibiotics lowered the rate of VAP and } \\
\text { decreased the requirement for IV antibiotics. }\end{array}$ \\
\hline $\begin{array}{l}\text { roneyama } \\
\text { tt al. } 1996^{6 i}\end{array}$ & 46 elderly nursing-home patients. & $\begin{array}{l}\text { During oral treatment for } 6 \text { months, febrile } \\
\text { days did not improve, but degradation of } \\
\text { febrile days was prevented by oral care in a } \\
\text { limited number of patients. }\end{array}$ & $\begin{array}{l}\text { Oral care may be useful to some extent in eld- } \\
\text { erly patients to prevent respiratory infections. }\end{array}$ \\
\hline $\begin{array}{l}\text { JeRiso et } \\
\text { al.. } 1996^{63}\end{array}$ & $\begin{array}{l}\text { Cardiovascular ICU subjects undergoing heart } \\
\text { surgery - } 173 \text { subjects in the test group. } 180 \\
\text { subjects in the placebo control group. Al } \\
\text { received systemic antibiotics. }\end{array}$ & $\begin{array}{l}69 \% \text { reduction in the incidence of total } \\
\text { respiratory tract infections in the chlorhexidine } \\
(\mathrm{CHX}) \text { group ( } p<0.05) \text {. A reduction in mortality } \\
\text { in the } \mathrm{CHX} \text {-group }(1.16 \% \text { vs. } 5.56 \%) \text {. }\end{array}$ & $\begin{array}{l}\mathrm{CHX} \text { oral rinse reduces the total nosocomial } \\
\text { respiratory infection rate and the use of non- } \\
\text { prophylactic systemic antibiotics in patients } \\
\text { undergoing heart surgery. }\end{array}$ \\
\hline $\begin{array}{l}\text { Yoneyama } \\
\text { t al., } 1999^{6}\end{array}$ & $\begin{array}{l}366 \text { eiderly residents from } 11 \text { nursing-homes. } \\
\text { Test group } 184 \text {, controls } 182 \text {. Follow-up } \\
\text { years. }\end{array}$ & $\begin{array}{l}\mathrm{RR}=1.67 \text { of developing pneumonia on no } \\
\text { active oral care compared with oral care } \\
(p=0.04) .\end{array}$ & $\begin{array}{l}\text { Oral care lowered the risk of pneumonia } \\
\text { in institutionalized elderly. }\end{array}$ \\
\hline $\begin{array}{l}\text { zourrier et } \\
\text { ㅋ.1. . 2000 }\end{array}$ & $\begin{array}{l}60 \text { ICU patients requiring mechanical ve } \\
\text { tion. Test group: } 30 \text { patients. } 30 \text { contro }\end{array}$ & $\begin{array}{l}8 / 30 \text { test patients and } 17 / 30 \text { control patients } \\
\text { had nosocomial infections. Number of VAP for } \\
1000 \text { days of mechanical ventilation was sig- } \\
\text { nificantly lower in the treated group ( } 10.7 \mathrm{vs} \\
32.3 \text { days, respectively, } \mathrm{P}<0.05 \text { ). Trend, but } \\
\text { not statistical difference, in a shorter length of } \\
\text { stay in the ICU, a shorter duration of mechani- } \\
\text { cal ventilation, and a lower mortality rate in the } \\
\text { treated group. }\end{array}$ & $\begin{array}{l}\text { Antiseptic decontamination of dental plaque } \\
\text { with } 0.2 \% \mathrm{CHX} \text { gel may reduce the incidence } \\
\text { of nosocomial infections. The correlation } \\
\text { between oral intervention and the incidence of } \\
\text { nosocomial pneumonia was, however, not } \\
\text { clearly stated. }\end{array}$ \\
\hline $\begin{array}{l}\text { Genuit et } \\
\text { all., } 200{ }^{66}\end{array}$ & $\begin{array}{l}95 \text { surgical ICU patients who required } \\
\text { mechanical ventilation. } 39 \text { historic contr } \\
\text { from hospital databases. Prospective st }\end{array}$ & $\begin{array}{l}\text { A ventilator-weaning protocol and } \mathrm{CHX} \text { led to } \\
\text { significant reduction and delay of occurrence } \\
\text { of VAP ( } 37 \% \text { overall. } 75 \% \text { for late VAP, } \\
p<0.05) \text {. }\end{array}$ & $\begin{array}{l}\text { Improved oral hygiene via topical } \mathrm{CHX} \text { with the } \\
\text { use of WP is effective in reducing the inci- } \\
\text { dence of VAP and the duration of mechanical } \\
\text { ventilation in surgical ICU patients. }\end{array}$ \\
\hline $\begin{array}{l}\text { 3ergmans } \\
\text { et al., } 2001^{\circ}\end{array}$ & $\begin{array}{l}\text { Test group: } 87 \text { patients. Placebo group: } \\
78 \text { patients. Control group: } 61 \text { patients } \\
\text { Prospective study from } 3 \text { ICUs over } 2 \\
\text { year period. }\end{array}$ & $\begin{array}{l}\text { Topical prophylaxis prevented acquired } \\
\text { oropharyngeal colonization ( } 10 \% \text { vs } 59 \% \\
\text { placebo and } 63 \% \text { control, } p<0.0001 \text { and } \\
p<0.00001 \text {, resp.). Incidence of VAP was } \\
10 \% \text { vs } 31 \% \text { in placebo }(p=0.001) \text { and } 23 \% \\
\text { in control }(p=0.04) \text {. }\end{array}$ & $\begin{array}{l}\text { Targeted approach to prevent oropharyngeal } \\
\text { colonization is an effective method of VAP } \\
\text { infection prevention. }\end{array}$ \\
\hline $\begin{array}{l}\text { Yoneyama } \\
\text { et al., 2002 }\end{array}$ & $\begin{array}{l}366 \text { elderly residents from } 11 \text { nursing-homes. } \\
\text { Test group } 184, \text { controls } 182 \text {. Follow-up } \\
\text { years. }\end{array}$ & $\begin{array}{l}\mathrm{RR}=1.67 \text { of developing pneumonia on no } \\
\text { active oral care compared with oral care } \\
(p=0.04) .\end{array}$ & $\begin{array}{l}\text { Oral care may be useful in preventing } \\
\text { pneumonia in older patients in nursing homes. }\end{array}$ \\
\hline $\begin{array}{l}\text { Adachi et } \\
\text { al., } 2002^{59}\end{array}$ & $\begin{array}{l}141 \text { elderly nursing home residents. Te: } \\
\text { group } 77 \text {, controls } 64 \text {. Followed for } 2 \text { y }\end{array}$ & $\begin{array}{l}\text { Weekly oral hygiene performed by dental } \\
\text { hygienists in test group. Test group had } \\
\text { significantly less }(p<0.05 \text { ) cultiviable oral } \\
\text { candida (at } 6 \text { months), less exhaled } \\
\text { methylmercaptan, fewer fevers, and fewer } \\
\text { deaths ( } 2 \text { vs } 8 \text { ) from aspiration pneumonia }\end{array}$ & $\begin{array}{l}\text { Oral care provided weekly by dental hygienists } \\
\text { was associated with reduced halitosis, fever } \\
\text { and fatal pneumonia. }\end{array}$ \\
\hline $\begin{array}{l}\text { Houston et } \\
\text { al., } 2002^{60}\end{array}$ & $\begin{array}{l}\text { A prospective, randomized, case-contrc } \\
\text { clinical trial. } 270 \text { in test group received } \\
\text { surgical oral rinse with } 0.12 \% \text { chlorhexi } \\
291 \text { controls rinsed with Listerine. }\end{array}$ & $\begin{array}{l}52 \% \text { reduction in nosocomial pneumonia } \\
(4 / 270 \text { vs } 9 / 291 ; p=0.21) \text {; patients intubated } \\
>24 \text { hr and cultured positive (all pneumonias } \\
\text { occurred in this group), } 58 \% \text { reduction }(4 / 19 \\
\text { vs } 9 / 18 ; p=.06) \text {; patients intubated }>24 \mathrm{hr} \text { and } \\
\text { cultures showing the most growth), } 71 \% \\
\text { reduction }(2 / 10 \text { vs } 7 / 10 ; p=.02)\end{array}$ & $\begin{array}{l}\mathrm{CHX} \text { rinse causes statistically significant } \\
\text { reduction in pneumonia in "high risk" } \\
\text { surgery patients: those who were intubated } \\
24 \text { hours or longer with positive cultures. }\end{array}$ \\
\hline
\end{tabular}


courage microbiological oropharyngeal growth will, in turn, reduce the risk for pneumonia. Among these factors are regular oral hygiene, reduction of oral inflammation through disease management and preservation of the body's own salivary antimicrobial defenses through limitation in the use of medications that directly or indirectly inhibit salivary flow. Although not a focus of the present article, measures that reduce the frequency and volume of inadvertent aspiration also will reduce pneumonia risk. Approaches that diminish susceptibility to infection-such as immunizations, management of concurrent disease and improved physical conditioning-improve the likelihood that the body's own defenses can successfully neutralize inoculi that are aspirated

\section{References}

1. Finegold SM. Aspiration pneumonia. Rev Infect Dis 1991; 13 (Suppl 9):S737-42.

2. Bartlett JG, Gorbach SL, Finegold SM. The bacteriology of aspiration pneumonia. Am J Med 1974; 56:202-7.

3. Marik PE. Aspiration pneumonitis and aspiration pneumonia. New Engl J Med 2001 2001; 344:665-71.

4. El-Solh AA, Pietrantoni C, Bhat A, Okada, et al. Colonization of dental plaques. A reservoir of respiratory pathogens for hospitalacquired pneumonia in institutionalized elders. Chest 2004; 126:1575-82.

5. Scannapieco FA, Stewart EM, Mylotte JM. Colonization of dental plaque by respiratory pathogens in medical intensive care patients. Crit Care Med 1992; 20:740-5.

6. Scannapieco FA, Mylotte JM. Relationships between periodontal disease and bacterial pneumonia. J Periodontol 1996; 67:1114-22.

7. Fourrier F, Duvivier B, Boutigny $\mathrm{H}$, et al. Colonization of dental plaque: a source of nosocomial infections in intensive care unit patients. Crit Care Med 1998; 26:301-8.

8. Russell SL, Boylan RJ, Kaslick RS, et al. Respiratory pathogen colonization of the dental plaque of institutionalized elders. Spec Care Dent 1999; 19:128-34.

9. Mojon P. Oral health and respiratory infection. J Can Dent Assoc 2002; 68:340-5.
10. El Solh AA, Pietrantoni $C$, Bhat A, et al. Microbiology of severe aspiration pneumonia in institutionalized elderly. Am J Respir Crit Care Med 2003; 167:1650-4.

11. Shay K. Infectious complications of dental and periodontal diseases in the elderly population. Clin Infect Dis 2002; 34:1215-23

12. Shay K, Ship JA. The importance of oral health in the older patient. J Amer Geriatr Soc 1995; 43:1414-1422.

13. Scannapieco FA, Bush RB, Paju S Associations between periodontal disease and risk for nosocomial bacterial pneumonia and chronic obstructive pulmonary disease. A systematic review. Ann Periodontol 2003; 8:54-69.

14. Muder, RR. Pneumonia in residents of longterm care facilities: Epidemiology, etiology, management, and prevention. Am J Med 1998; 105:319-30

15. Loeb MB. Community acquired pneumonia in older people: The need for a broader perspective. J Am Geriatr Soc 2003; 51:539-43.

16. Fiske J, Lloyd HA. Dental needs of residents and carers in elderly peoples' homes and carers' attitudes to oral health. Eur J Prosthodont Restor Dent 1992; 1:91-5.

17. Kiyak HA, Grayston MN, Crinean CL. Oral health problems and needs of nursing home residents. Community Dent Oral Epidemiol 1993; 21:49-52.

18. Hardy DL, Brangan PP, Darby ML, et al. Self-report of oral health services provided by nurses' aides in nursing homes. J Dent Hyg 1995; 69:75-82.

19. Chalmers JM, Levy SM, Buckwalter KC, et al. Factors influencing nurses' aides' provision of oral care for nursing facility residents. Special Care Dentist 1996; 16:71-9.

20. Wårdh I, Andersson L, Sörensen S. Staff attitudes to oral health in the elderly. A comparative study of registered nurses, nursing assistants and home care aides. Gerodontology 1997; 14:28-32.

21. Frenkel HF: Behind the scenes: Care staff observations on delivery of oral health in nursing homes. Gerodontology 1999; 16:75-80.

22. Chung J-P, Mojon P, Budtz-Jørgensen E. Dental care of elderly in nursing homes: Perceptions of managers, nurses, and physicians. Special Care Dentist 2000; 20:12-7.

23. Fedson DS, Shapiro ED, LaForce FM, et al. Pneumococcal vaccine after 15 years of use. Another view. Arch Intern Med 1994; 154:2531-5.
24. Chastre J, Fagon JY. Ventilator-associated pneumonia. Am J Respir Crit Care Med 2000; 165:867-903.

25. Langmore SE, Skarupski KA, Park PS, et al. Predictors of aspiration pneumonia in nursing home residents. Dysphagia 2002; 17:298-307

26. Thompson RS, Hall NK, Szpiech M Hospitalization and mortality rates for nursing home-acquired pneumonia. J Fam Pract 1999; 48:291-3.

27. Medina-Walpole AM, Katz PR. Nursing home-acquired pneumonia. J Amer Geriatr Soc 1999; 47:1005-15.

28. Martin BJW, Corlew MM, Wood H, et al. The association of swallowing dysfunction and aspiration pneumonia. Dysphagia 1994; 9:1-6.

29. Mylotte JM. Naughton B, Saludadas C, et al. Validation and application of the pneumonia prognosis index to nursing home residents with pneumonia. J Amer Geriatr Soc 1998; 46:1538-44.

30. Marik PE, Careau P. The role of anaerobes in patients with ventilator-associated pneumonia and aspiration pneumonia. Chest 1999; 115:178-83.

31. Terpenning MS, Taylor GW, Lopatin DE, et al. Aspiration pneumonia: Dental and oral risk factors in an older veteran population. J Amer Geriatr Soc 2001; 49:557-63.

32. Mehr DR, Binder EF, Kruse RL, et al. Clinical findings associated with radiographic pneumonia in nursing home residents. J Fam Pract 2001;50:931-7.

33. Terpenning MT, Bretz W, Lopatin DE, et al. Bacterial colonization of saliva and plaque in the elderly. Clin Infect Dis 1993; 16 (Suppl 4): $5314-6$

34. Craven DE, Stever KA, Barber TW. Preventing nosocomial pneumonia: State of the art and perspectives for the 1990s. Am J Med 1991; 91 (Suppl 3B) 44S-53S.

35. Mylotte J. Nursing home-acquired pneumonia. Clin Infect Dis 2002; 35:1205-11.

36. Langmore SE, Terpenning, MS, Schork A, et al. Predictors of aspiration pneumonia: How important is dysphagia? Dysphagia 1998; 13(2):69-81.

37. Bashford $G$, Bradd P. Drug-induced parkinsonism associated with dysphagia and aspiration: A brief report. J Geriatr Psychiatry Neurol 1996; 9:133-5. 
38. Thai PH, Shuman SK, Davidson GB. Nurses dental assessments and subsequent care in Minnesota nursing homes. Special Care Dentist 1997; 17: 13-8.

39. Bartlett JG, O'Keefe P, Tally FP, et al. Bacteriology and treatment of hospitalacquired pneumonia. Arch Intern Med 1986; 146:868-71

40. Moser KM, Mauer J, Jasey L, et al. Sensitivity, specificity, and risk of diagnostic procedures in a canine model of Streptococcus pneumoniae pneumonia. Am Rev Respir Dis 1982; 125:436-442.

41. Loesche WJ, Schork A, Terpenning MS, et al. Factors which influence levels of selected organisms in saliva of older individuals. $J$ Clin Microbiol 1995; 33:2550-7.

42. Valenti WM, Trudell RG, Bentley DW. Factors predisposing to oropharyngeal colonization with gram-negative bacilli in the aged. New Engl J Med 1978; 298:1108-11.

43. Gibbons RJ, Hay DI, Childs WC 3rd, et al. Role of cryptic receptors (cryptitopes) in bacterial adhesion to oral surfaces. Arch Oral Biol 1990; 35 (Suppl):107S-14S.

44. Johanson WG Jr., Higuchi JH, Chaudhuri TR, et al. Bacterial adherence to epithelial cells in bacillary colonization of the respiratory tract. Amer Rev Res Dis 1980; 121:55-63.

45. Scannapieco FA. The role of oral bacteria in respiratory infection. J Periodontol 1999; 70.793-802.

46. Gibbons RJ; Etherden I. Fibronectin-degrading enzymes in saliva and their relation to oral cleanliness. J Perio Res 1986; 21:386-95.

47. Sreebny LM. Saliva in health and disease: An appraisal and update. Int Dent J 2000; 50:140-61

48. Fox PC. Acquired salivary dysfunction. Drugs and radiation. Ann NY Acad Sci 1998;842:132-7.

49. Wu AJ, Ship JA. A characterization of major salivary gland flow rates in the presence of medications and systemic diseases. Oral Surg Oral Med Oral Pathol 1993; 76:301-6.

50. Berkey DB, Berg RG, Ettinger RL, et al. Research review of oral health status and service use among institutionalized older adults in the United States and Canada. Special Care Dentist 1991; 11:131-6.

51. Bonten MJM, Gaillard CA, van Tiel FH, et al. The stomach is not a source for colonization of the upper respiratory tract and pneumonia in ICU patients. Chest 1994; 105:878-84
52. Croghan JE, Burke EM, Caplan S, et al. Pilot study of 12-month outcomes of nursing home patients with aspiration on videofluoroscopy. Dysphagia 1994; 9:141-6.

53. Kikuchi R, Watabe N, Konno T, et al. High incidence of silent aspiration in elderly patients with community-acquired pneumonia. Am J Respir Crit Care Med 1994; 150:251-3.

54. Musson ND, Frye GD, Nash M. Silver spoons: Supervised volunteers provide feeding of patients. Geriatr Nurs 1997; 18:18-9.

55. Mokhlesi B, Logemann JA, Rademaker AW, et al. Oropharyngeal deglutition in stable COPD. Chest 2002; 121:361-9.

56. Dormenval V, Mojon P, Budtz-Jorgensen E. Associations between self-assessed masticatory ability, nutritional status, prosthetic status and salivary flow rate in hospitalized elders. Oral Dis 1999; 5:32-8.

57. Yoshikawa, TT. Treatment of nursing homeacquired pneumonia. J Am Geriatr Soc 1991; 39:1040-1.

58. Holm-Pedersen P, Agerbaek N, Theilade E. Experimental gingivitis in young and elderly individuals. J Clin Periodontol 1975; 2:14-24.

59. Adachi M, Ishihara $\mathrm{K}, \mathrm{Abe} \mathrm{S}$, et al. Effect of professional oral health care on the elderly living in nursing homes. Oral Surg Oral Med Oral Pathol Oral Radiol Endod 2002; 94:1915.

60. Houston S, Hougland P, Anderson JJ, et al. Effectiveness of $0.12 \%$ chlorhexidine gluconate oral rinse in reducing prevalence of nosocomial pneumonia in patients undergoing heart surgery. Am J Crit Care 2002; 11:567-70.

61. Pugin J; Auckenthaler R, Lew DP, et al. Oropharyngeal decontamination decreases incidence of ventilator-associated pneumonia. JAMA 1991; 265:2704-10.

62. Yoneyama $T$, Yoshinda $M$, Matsui $T$, et al. Oral care and pneumonia (letter). Lancet 1999; 354:515.

63. DeRiso AJ, Ladowski JS, Dillon, et al. Chlorhexidine gluconate $0.12 \%$ oral rinse reduces the incidence of total nosocomial respiratory infection and nonprophylactic systemic antibiotic use in patients undergoing heart surgery. Chest 1996; 109:1556-61.

64. Yoneyama T, Hashimoto K, Fukuda $\mathrm{H}$, et al. Oral hygiene reduces respiratory infections in elderly bed-bound nursing home patients. Arch Gerontol Geriatr 1996;22:11-9.
65. Fourrier F, Cau-Pottier E, Boutigny H, et al. Effects of dental plaque antiseptic decontamination on bacterial colonization and nosocomial infections in critically ill patients. Intensive Care Med 2000;26:1239-47.

66. Genuit T, Bochicchio G, Napolitano LM, et al. Prophylactic chlorhexidine oral rinse decreases ventilator-associated pneumonia in surgical ICU patients. Surg Infect 2001;2:5-18.

67. Bergmans DC, Bonten MJ, Gaillard CA, et al. Prevention of ventilator-associated pneumonia by oral decontamination. A prospective, randomized, double-blind, placebo-controlled study. Am J Respir Crit Care Med 2001;164:382-8.

68. Yoneyama T, Yoshida M, Mukaiyama $\mathrm{H}$, et al. Oral care reduces pneumonia of elderly patients in nursing homes. J Am Geriatr Soc 2002; 50:430-3.

69. Day J, Martin MD, Chin M. Efficacy of a sonic toothbrush for plaque removal by caregivers in a special needs population. Special Care Dentist 1998; 18:202-6.

70. Kambhu PP, Levy SM. An evaluation of the effectiveness of four mechanical plaqueremoval devices when used by a trained care-provider. Special Care Dentist 1993; 13:9-13.

71. Persson RE, Truelove EL, LeResche LO, et al. Therapeutic effects of daily or weekly chlorhexidine rinsing on oral health of a geriatric population. Oral Surg Oral Med Oral Pathol 1991; 72:184-91.

72. Simons D, Brailsford SR, Kidd EAM, et al. The effect of medicated chewing gums on oral health in frail older people: A 1-year clinical trial. J Am Geriatr Soc 2002; 50:1348-53.

73. Slots J, Rams TE, Schonfeld SE. In vitro activity of chlorhexidine against enteric rods, pseudomonads and acinetobacter from human periodontitis. Oral Microbiol Immunol 1991; 6:62-4. 